\title{
www.czasopisma.pan.pl \\ Vibratory Machining Effect on the Properties of the Aaluminum Alloys Surface
}

\author{
D. Bańkowski *, S. Spadło \\ Department of Computer Science and Armament, Kielce University of Technology, \\ ul. Tysiąclecia Państwa Polskiego 7, 25-314 Kielce, Poland: \\ * Corresponding author. E-mail address: dbankowski@tu.kielce.pl
}

Received 28.06.2017; accepted in revised form 22.08.2017

\begin{abstract}
The article presents an example of finishing treatment for aluminum alloys with the use of vibration machining, with loose abrasive media in a closed tumbler. For the analysis of selected properties of the surface layer prepared flat samples of aluminum alloy PA6/2017 in the state after recrystallization. The samples in the first stage were subjected to a treatment of deburring using ceramic media. In a second step polishing process performed with a strengthening metal media. In addition, for comparative purposes was considered. only the case of metal polishing. The prepared samples were subjected to hardness tests and a tangential tensile test. As a result of finishing with vibratory machining, it was possible to remove burrs, flash, rounding sharp edges, smoothing and lightening the surface of objects made. The basic parameters of the surface geometry were obtained using the Talysurf CCI Lite - Taylor Hobson optical profiler. As a result of the tests it can be stated that the greatest reduction of surface roughness and mass loss occurs in the first minutes of the process. Mechanical tests have shown that the most advantageous high values of tensile strength and hardness are obtained with two-stage vibration treatment, combination of deburring and polishing. Moreover the use of metal media resulted in the strengthening of the surface by pressure deburring with metal media.
\end{abstract}

Keywords: Surface finishing, Tumble finishing, Vibratory machining, Surface roughness

\section{Introduction}

Aluminum alloys have a wide range of applications thanks to their good weight to strength ratio $[1,2]$. They are used for loadbearing elements of vehicles, ships, cranes, bridges. There are used also for elements of tanks, mining equipment, and extensive use in the aerospace industry. In addition, aluminum alloys are used in the production of architectural elements such as window profiles, door profiles, ladders, fences, balustrades and radiators. Aluminum objects are usually made by metal forming processing but also by casting. Aluminum alloys have an average mechanical strength, good corrosion resistance and impact resistance [3]. They have average fatigue strength. Aluminum alloys are perfect for machining and very often polished. The purpose of this article was to determine and analyzed the effect of vibratory machining on selected properties of the surface layer state. Compared the results obtained after the deburring treatment, after the polishing with metal media and combination deburring with polishing.

\section{Vibratory machining}

Vibratory machining is one of the production techniques of the finished products with low surface roughness [4]. Vibratory finishing how to the processing of erosion, electrical discharge machining, microwelding, electrochemical machining, water jet cutting (AWJ), laser cutting are often included in the "nontraditional" or "non-conventional" group of machining methods 
$[5,6]$. Opposite to the "conventional" group milling, drilling, turning, grinding [7-9] etc. Vibratory machining is a process based on the chemical-mechanical finishing of rough surfaces [10]. Commonly vibratory machining is also referred to as vibration, rotor machining, rotor finish, tumbling, trowelling, or micro machining processes $[11,12]$. Vibratory machining is often used as a finishing, to deburring, remove burrs, rounding edge or smoothing to polishing to gloss [13]. The process takes place in closed tumbler containing the workpieces, working medium in the form of suitably selected abrasive or polishing media, and liquid lubricant - working fluid [14-16]. Process kinematics consists in moving workpieces relative to abrasive components. Vibration and gravity movements cause continuous movement of the abrasive material and workpieces placed freely in the machine working container [17]. This leads to the interaction between the materials contained in the container and the abrasion of surface roughness[18]. The example of the device is shown in Figure 1.

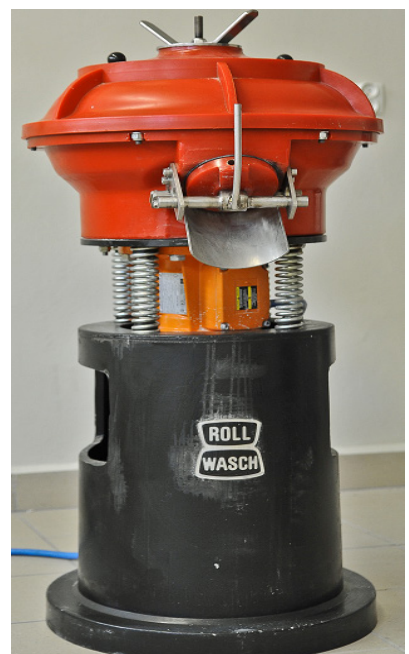

Fig. 1. Rollwasch SMD-25-R

Vibratory machining has a very varied and large applications. There is commonly used in surface cleaning, deburring and flowing, rounding, sharpening, smoothing, brightening and burnishing operations. [19] An excellent example of the application of this method is the jewelry industry, eg. metal polishing jewelry [20], of plastics, natural bones and precious stones. This technique is used, among others for the processing of small objects of the type: construction and furniture fittings, buckles, keys, clothing and footwear accessories, fishing tackle, electronic components, rims, etc. of all grades of steel, cast iron, nonferrous and precious metals, plastics, stones, wood [21]

The main purpose of surface treatment is to increase the durability of machine parts and tools. This is related to the reduction of material losses, energy and product quality. Surface treatment ensures that the product performs better in mechanical properties, abrasion resistance, high temperature resistance and corrosion-erosion. It is possible to replace high-alloy steels or hard-to-reach materials - medium and low alloy steels with a suitable surface layer. This layer significantly changes the properties of the product. All phenomena of fabrication and shaping of surface layers of machine parts and tools are called surface engineering. From produced layers are required pre-set and repetitive properties that guarantee an increase in their service life[22].

Through the top layer (of metal) material layer should be understood of course limited surface area and comprising a material having properties different from the properties of the core material. The cause for changing the surface layer properties can be single or combined forces [22]:

- mechanical

- electric,

- warm

- chemical factors.

Surface layers and coatings are commonly called surface layers. Mechanical methods utilize tool pressure or kinetic energy of a tool or particle to quench cold metal (metal alloys) or to obtain a coating on a cold metal substrate (detonating application) [22].

\section{Research object}

Test objects were made in the form of samples for static tensile test of PA6/2017 aluminum alloy, chemical composition is shown in Table 1. The thickness of samples was of $1 \mathrm{~mm}$, a width of $10 \mathrm{~mm}$ and a length measuring section $50 \mathrm{~mm}$. Species PA6 are commonly used for mold construction thanks to good polishing conditions. This alloy is characterized by good strength properties and high tensile strength and fatigue. Suitable for welding, is moderately resistant to corrosion. Samples were made of flat sheet cutting technique of high pressure water and abrasive jet machining (AWJM). Then samples to reflect the properties of thin castings were recrystallized to remove the effect of plastic deformation.

Table 1.

Chemical composition of aluminum alloy PA6, \% [23].

\begin{tabular}{ccccccccc}
\hline & $\mathrm{Si}$ & $\mathrm{Fe}$ & $\mathrm{Cu}$ & $\mathrm{Mn}$ & $\mathrm{Mg}$ & $\mathrm{Cr}$ & $\mathrm{Zn}$ & $\mathrm{Ti}$ \\
\hline $\min$ & 0.20 & 0.60 & 3.50 & 0.40 & 0.40 & 0.08 & 0.23 & 0.17 \\
\hline $\max$ & 0.80 & 0.80 & 4.50 & 1.00 & 1.00 & 0.12 & 0.27 & 0.23 \\
\hline
\end{tabular}

The research was carried out on an Rollwasch SMD-25-R vibratory tumbler with a $25 \mathrm{dm}^{3}$ bowl of tumbler. The samples in the first stage were subjected to a pre-treatment of deburring using ceramic media CB 20T- Figure 2. It is designed for roughing and deburring [24]. The duration of deburring was 20, 40 and $60 \mathrm{~min}$. In a second step polishing process performed with a strengthening metal fittings - polishing, metal media SB 3,1 lotto - Figure 3. Stainless steel are recommended for burnishing and polishing of steel and non-ferrous metals [25].

In addition, for comparative purposes, only the case of metal polishing alone was considered. Polishing was 20, 40, $60 \mathrm{~min}$. The frequency of the vibration container was $2500 \mathrm{~Hz}$. Deburring and polishing processes were carried out on wet add approx. 150 $\mathrm{ml}$ liquid adjuvant FE-L120-B32/R. On the basis of the studies compared the surfaces in the initial state - recrystallization, the surface after deburring, the surface after polishing and surface after combination deburring and polishing. 


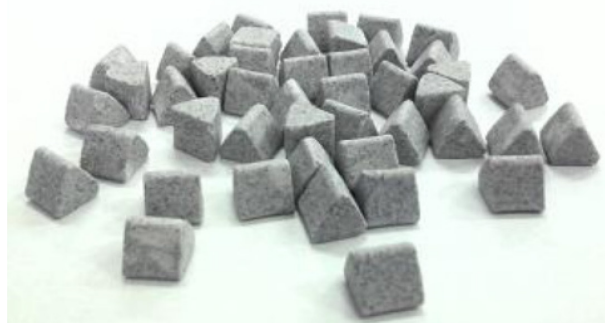

Fig. 2. Ceramic media CB 20T - density $2.4-2.7 \mathrm{~kg} / \mathrm{dm}^{3}$

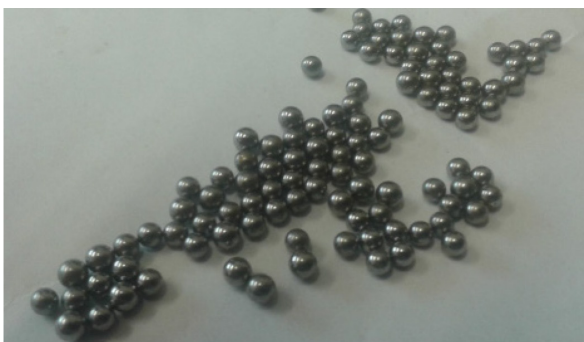

Fig. 3. Metal media SB 3,1 lotto (round)

\section{Achieved results}

Objects in the form of a standard sample, made using a high pressure abrasive waterjet cutting technology - AWJM were polished with ceramic media on 20, 40, 60 minutes, after which the sample was subjected to treatment of polishing with metal media on 20, 40, 60 minutes. It was also considered the case of the samples subjected to polishing adequately only by $20,40,60$ minutes. Sample were measured weights before machining and after vibration smoothing. In order to determine relative weight loss, expressed in \%o, was calculated from the mass loss relative to the mass (of the part) before the smoothing operation.

Standardized samples were subjected to static tensile test. The obtained results are summarized in Table 2. They allowed to calculate the tensile strength and elongation of the objects tested. Surface hardness has also been tested - Vickers method. Load was $50 \mathrm{~g}$, average values were listed in Table 2

Table 2.

Results of measurements of weight loss and mechanical properties.

\begin{tabular}{lccccc}
\hline $\begin{array}{c}\text { Type and duration of } \\
\text { machining }\end{array}$ & $\begin{array}{c}\text { Mass } \\
\text { loss, } \\
\mu \mathrm{g}\end{array}$ & $\begin{array}{c}M M R \\
\%\end{array}$ & $\begin{array}{c}R m, \\
\mathrm{MPa}\end{array}$ & $A, \%$ & $H V$ \\
\hline before machining & - & - & 63.34 & $39.9 \%$ & 22.1 \\
\hline deburring 20 min & 5.65 & 1.56 & 66.12 & $40.4 \%$ & 26.4 \\
\hline deburring 40 min & 10.20 & 2.81 & 68.06 & $45.4 \%$ & 27.4 \\
\hline deburring 60 min & 13.25 & 3.67 & 69.20 & $48.5 \%$ & 28.2 \\
\hline $\begin{array}{l}\text { deburring 20 min and } \\
\text { polishing 20 min }\end{array}$ & 7.75 & 2.14 & 71.21 & $43.4 \%$ & 29.3 \\
\hline $\begin{array}{l}\text { deburring 40 min and } \\
\text { polishing 40 min }\end{array}$ & 16.75 & 4.63 & 73.34 & $40.6 \%$ & 35.3 \\
\hline $\begin{array}{l}\text { deburring 60 min and } \\
\text { polishing 60 min }\end{array}$ & 23.45 & 6.48 & 74.28 & $45.7 \%$ & 37.9 \\
\hline polishing 20 min & 1.75 & 0.48 & 70.34 & $43.7 \%$ & 27.6 \\
\hline polishing 40 min & 2.90 & 0.80 & 71.35 & $45.1 \%$ & 28.8 \\
\hline polishing 60 min & 3.35 & 0.92 & 72.75 & $42.0 \%$ & 29.6 \\
\hline
\end{tabular}

The use of only ball machining resulted in a very small decrease in workpiece weight $3.35 \mu \mathrm{g}$ (seven times less weight loss at combination $60 \mathrm{~min}$ of deburring treatment and $60 \mathrm{~min}$ polishing treatment $-23.45 \mu \mathrm{g}$ )

The greatest elongation $A=48.5 \%$ is characterized by 60 minutes of deburring with ceramic moldings. The plasticity of the material improved while improving the tensile strength ( $R m$ of about $70 \mathrm{MPa}$ ). Polishing for $60 \mathrm{~min}$ and the combination of polishing and deburring results in similar results of objects $A=45 \%$.

Then was made the measurements the geometrical surface structure. The surface roughness were measured by using optical profilometer Talysurf CCI Lite - Taylor Hobson. Number of measurement points amounted to $1024 \times 1024$. The analysis of the 3D and 2D surface topography for all samples was carried out. Measurements using a optical profilometer allowed to draw Table 3 which shows the basic parameters of the surface geometry texture. It must define the parameters geometrical product specifications contained in Table 3. According to ISO $25178 \mathrm{Sa}$ parameter is defined as the arithmetic average surface height. Parameter $S z$ is the maximum height of the surface, and parameter $S v$ is the maximum cavity surface. Parameter highest peak area $S p$ is the difference between $S z$ and $S v$. $R a$ is a deviation of the arithmetic mean of the roughness profile. $R z$ is maximum height of roughness profile, equal to the sum of the maximum height of the peak $R p$ and the maximum depth of the valley of the roughness profile $R v$ [26]. Figure 4 is shown dependence of the arithmetic average surface height $S a$ on time and type of treatment.

Table 3.

The values of the geometrical product specifications.

\begin{tabular}{lcccccc}
$\begin{array}{l}\text { Type and duration of } \\
\text { machining }\end{array}$ & $\begin{array}{c}S a, \\
\mu \mathrm{m}\end{array}$ & $\begin{array}{c}S z, \\
\mu \mathrm{m}\end{array}$ & $\begin{array}{c}S v, \\
\mu \mathrm{m}\end{array}$ & $\begin{array}{l}S p, \\
\mu \mathrm{m}\end{array}$ & $\begin{array}{l}R a, \\
\mu \mathrm{m}\end{array}$ & $\begin{array}{l}R z, \\
\mu \mathrm{m}\end{array}$ \\
\hline before machining & 0.35 & 12.72 & 5.77 & 6.95 & 0.27 & 2.93 \\
\hline deburring 20 min & 1.29 & 22.48 & 14.14 & 8.34 & 1.14 & 8.24 \\
\hline deburring 40 min & 1.06 & 15.73 & 8.98 & 6.75 & 0.87 & 6.18 \\
\hline deburring 60 min & 1.02 & 15.33 & 10.04 & 5.29 & 0.81 & 5.29 \\
\hline $\begin{array}{l}\text { deburring 20 min and } \\
\text { polishing 20 min }\end{array}$ & 0.76 & 7.52 & 4.39 & 3.13 & 0.48 & 2.81 \\
$\begin{array}{l}\text { deburring 40 min and } \\
\text { polishing 40 min }\end{array}$ & 0.71 & 6.88 & 4.03 & 2.85 & 0.45 & 2.52 \\
\hline $\begin{array}{l}\text { deburring 60 min and } \\
\text { polishing 60 min }\end{array}$ & 0.64 & 6.24 & 3.16 & 3.08 & 0.38 & 2.17 \\
\hline $\begin{array}{l}\text { polishing 20 min } \\
\text { polishing 40 min }\end{array}$ & 0.89 & 10.15 & 5.68 & 4.47 & 0.60 & 3.17 \\
\hline polishing 60 min & 0.75 & 8.60 & 5.07 & 3.52 & 0.46 & 3.21 \\
\hline
\end{tabular}

Machining with loose abrasive media increases the average surface roughness $S a$ after deburring from $0.35 \mu \mathrm{m}$ to even 1.29 $\mu \mathrm{m}$ after deburring for $20 \mathrm{~min}$. Longer machining times result in a linear decrease in the $S a$ parameter along with machining time Figure 4. Vibratory machining with abrasive media allows surface preparation to coating surface. Despite the worsening of the surface roughness of the sample they are characterized by higher hardness and tensile strength. 


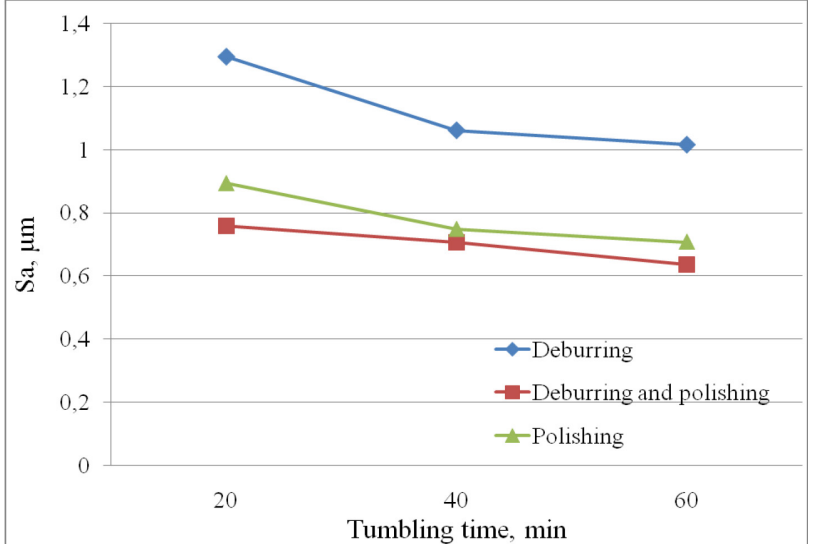

Fig. 4. Graph of the average surface roughness Sa on the duration of vibratory machining

\section{General remarks}

On the basis of the collected hardness data and tensile strength of the machining time created chart number 5 and 6 . There were three cases applied: the first effect of polishing the loose ceramic media, second impact polishing with steel balls and the third case of samples first deburred with ceramic and then polished with steel balls. The results indicate that it is best to lead vibro-abrasive machining process in two stages. That is, in the first step use the abrasive-polishing media for treatment deburring, smoothing, edge rounding and after this step use polishing process using a metal media for strengthening surface.

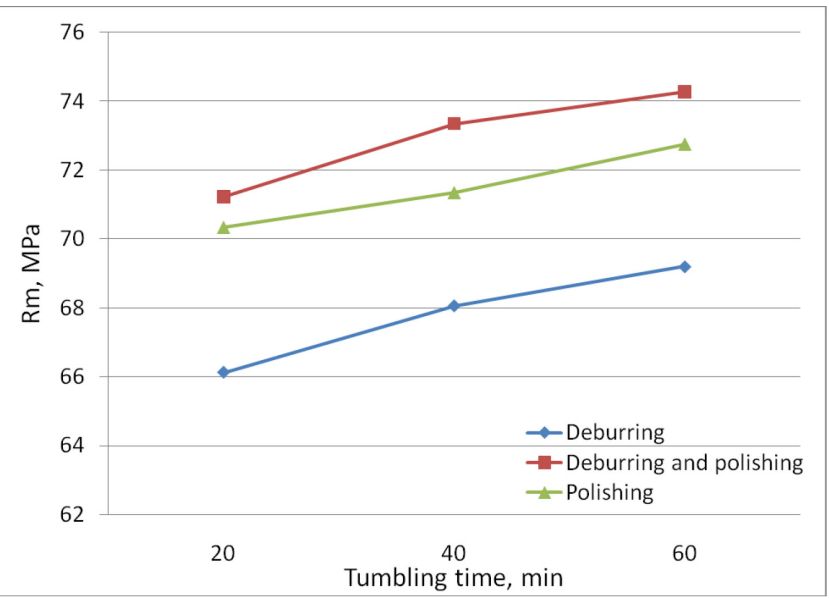

Fig. 5. Graph of tensile strength $(R m)$ dependence from duration of vibratory machining

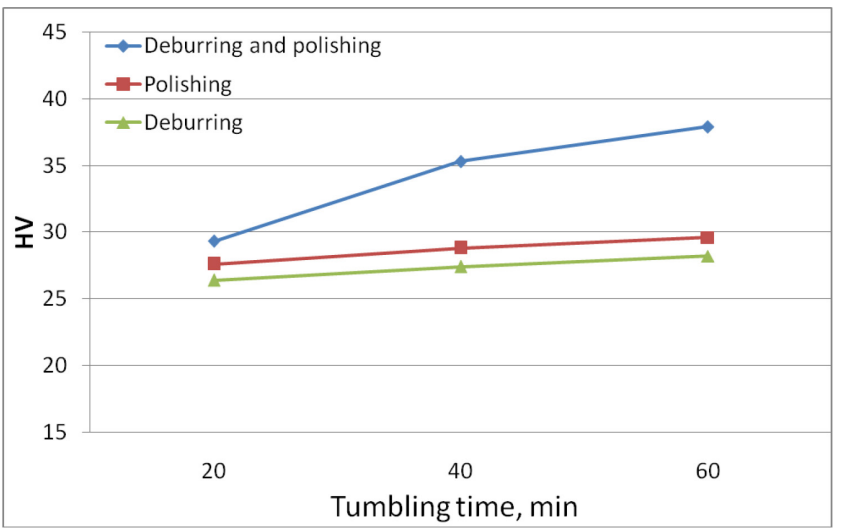

Fig. 6. Graph of hardness dependence $(H V)$ on the duration of vibratory machining

The first stage of deburring with using ceramic media removed the burrs, rounded edges and reduced surface roughness. The deburring treatment drown the surface of the largest elevations (Sp). This parameter resulted in a reduction of 60 minutes from $6.95 \mu \mathrm{m}$ to $5.29 \mu \mathrm{m}$. Polishing with metal fittings on 60 minutes, after deburring treatment was reduced the $\mathrm{Sp}$ parameter from $5.29 \mu \mathrm{m}$ to $3.08 \mu \mathrm{m}$. But only polishing with metal on 60 minutes resulted in the surface with the highest elevation (Sp) to $3.09 \mu \mathrm{m}$.

It is important to note that the most advantageous high tensile strength values are also obtained with a two-stage vibratory machining, tensile strength - Rm has reached 74.3 MPa. The selfdeburring treatment for one hour gave a tensile strength of 69.2MPa, while polishing itself with metal media gave $\mathrm{Rm}=72.8 \mathrm{MPa}$. From the graph number 5, can conclude that the tensile strength $R m$ increases linearly with increasing treatment time.

Analogous results were obtained for surface hardness figure 6. The highest hardness occurred after 60 minutes deburring and 60 min polishing with metal fittings $-H V=37.9$. Only deburring treatment for $60 \mathrm{~min}$ - showed $28,2 \mathrm{HV}$, and only polishing treatment $-29.6 \mathrm{HV}$.

Figure 7 is shown samples made of aluminum alloy PA6 before and after vibratory machining.

The PA6 aluminum alloy material was characterized by good properties as for aluminum alloys. It should be emphasized, however, that in everyday objects materials we use with much better endurance and hardness properties. It is advisable to carry out a wider study on other materials to confirm the properties that strengthen the vibration treatment.

Figure 8-11 are shown 3D optical surface of samples before and after vibratory machining. 


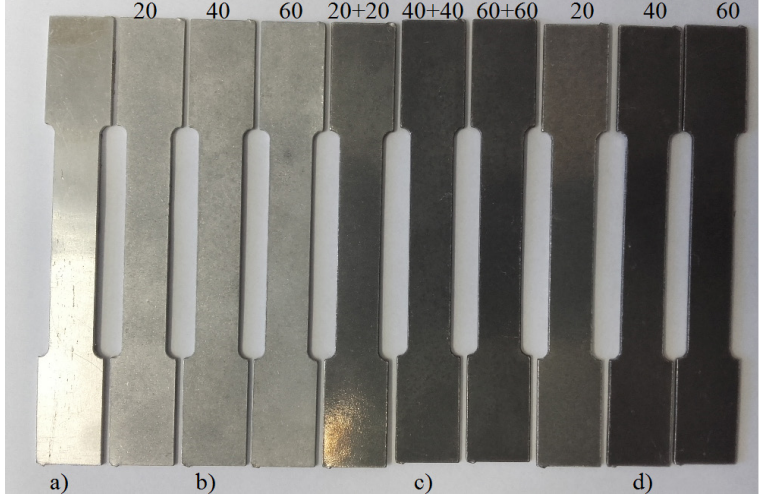

Fig. 7. The samples a) before machining, b) after deburring on 20, $40,60 \mathrm{~min}, \mathrm{c}$ ) after deburring on $20+$ polishing on $20 \mathrm{~min}$,

$40 \mathrm{~min}, 60 \mathrm{~min}, \mathrm{~d}$ ) after polishing on 20, $40 \mathrm{~min}, 60 \mathrm{~min}$

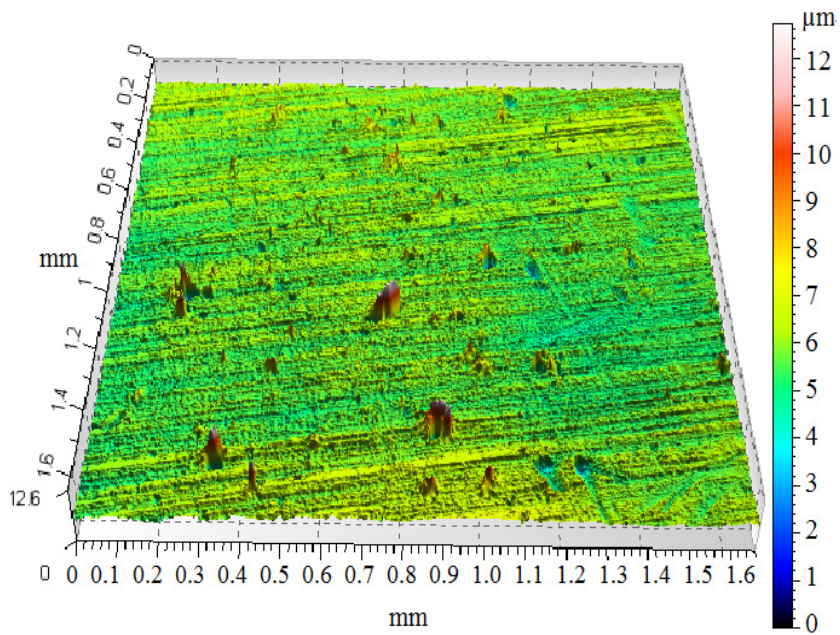

Fig. 8. 3D optical surfaces of the sample before machining.

$$
S a=0.3501 \mu \mathrm{m}
$$

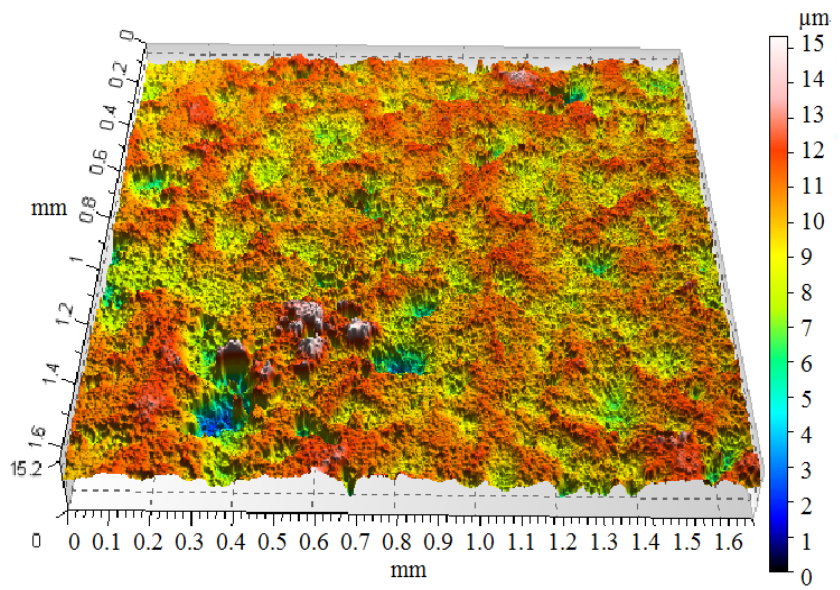

Fig. 9. 3D optical surfaces of the sample after vibro-abrasive deburring on $60 \mathrm{~min} ; S a=1.0163 \mu \mathrm{m}$

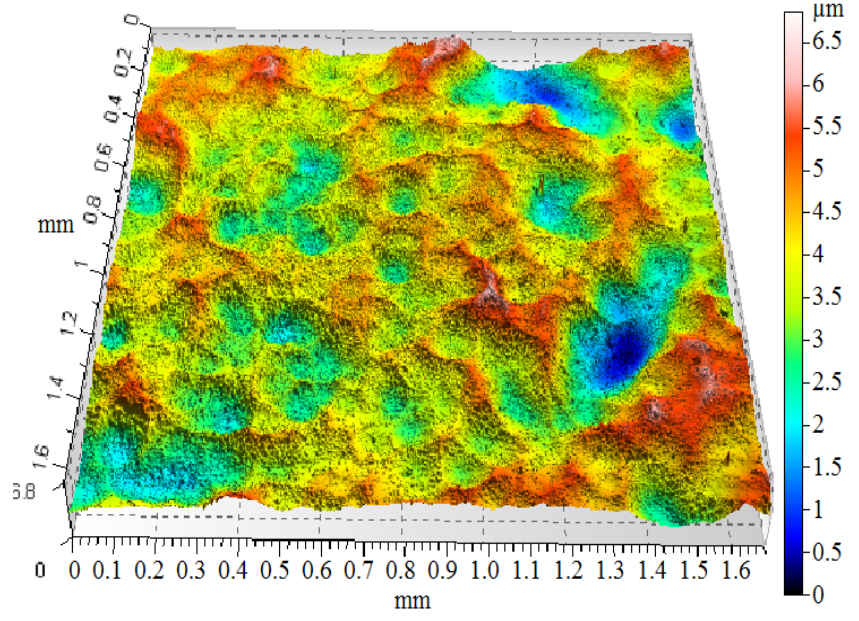

Fig. 10. 3D optical surfaces of the sample after vibro- polishing on $60 \mathrm{~min} ; S a=0.7074 \mu \mathrm{m}$

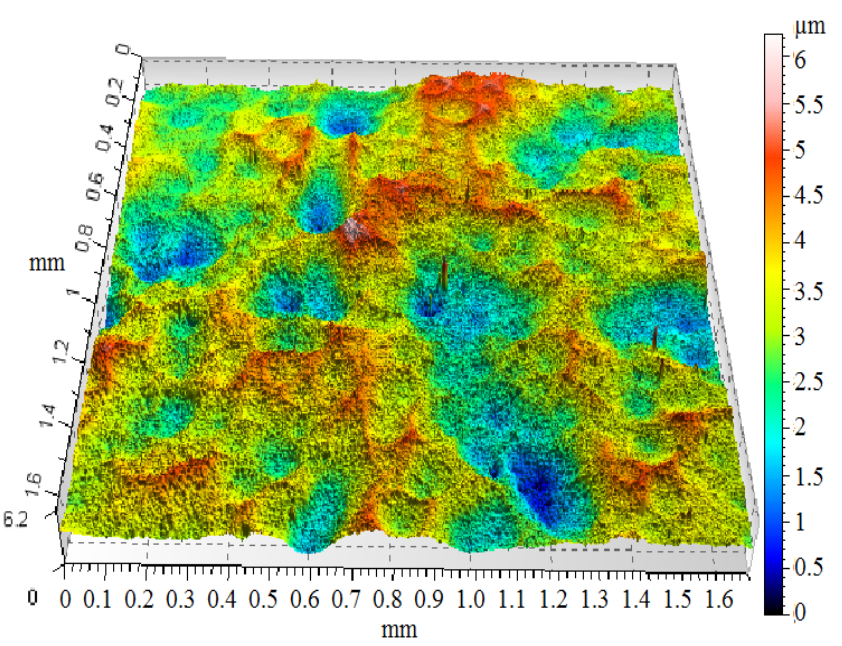

Fig. 11. 3D optical surfaces of the sample after vibro-abrasive deburring on $60 \mathrm{~min}$. and polishing on $60 \mathrm{~min} ; S a=0.6365 \mu \mathrm{m}$

\section{Conclusions}

The use of vibratory machining has a positive effect on the smoothing and brightening of the surface.

The surface after vibratory machining is characterized by anisotropic structure, there are no signs of the preceding manufacturing processes.

The greatest changes in surface roughness and mass loss are observed in the first minutes of treatment. Longer periods of treatment will cause linear defects in workpiece mass.

Geometric surface parameters also decrease linearly with machining time $S a=1.0163 \mu \mathrm{m}$ to $S a=0.6365 \mu \mathrm{m}$.

The use of vibration treatment for samples made of aluminium alloy PA6 after recrystallization causes increased tensile strength of $63.3 \mathrm{MPa}$ to $74.3 \mathrm{MPa}$ and hardness of 22.1 $\mathrm{HV}$ to $37.9 \mathrm{HV}$ 
The best effect were in the two-stage vibration treatment. First grind the surfaces, smooth with abrasive media and then polishing using metal media.

\section{References}

[1] Mola, R., Bucki, T. \& Dziadoń, A. (2017). Microstructure of the bonding zone between AZ91 and AlSi17 formed by compound casting. Archives of Foundry Engineering. 17(1), 202-206. DOI: 10.1515/afe-2017-0036.

[2] Patejuka, A. \& Poniatowska, M. (2007). Effects of finishing on the surface quality of precision castings. Archives of Foundry Engineering. 7(1), 93-96.

[3] Konieczny, M. (2013). Mechanical properties and deformation behavior of laminated $\mathrm{Ni}-(\mathrm{Ni} 2 \mathrm{~A} 13+\mathrm{NiA} 13)$ and $\mathrm{Ni}-(\mathrm{Ni3} \mathrm{Al}+\mathrm{NiAl})$ composites. Materials Science and Engineering A-Structural Materials Properties Microstructure and Processing. 586(1), 11-18.

[4] Bańkowski, D., Spadło, S. (2015). Influence of the smoothing conditions in vibro-abrasive finishing and deburring process for geometric structure of the surface machine parts made of aluminum alloys EN AW2017, Proceedings of 24th International Conference on Metallurgy and Materials, METAL 2015 (pp. 1062-1068).

[5] Bańkowski, D., Krajcarz D., Młynarczyk, P. (2017). Deburring and smoothing the edges using vibro-abrasive machining. 12th International Scientific Conference of Young Scientists on Sustainable, Procedia Engineering; Volume: 192 (pp. 28-33).

[6] Hlavac, L., Krajcarz, D., Hlavacova, I. \& Spadło, S. (2017). Precision comparison of analytical and statistical-regression models for AWJ cutting. Precision Engineering. Journal of the International Societies for Precision Engineering and Nanotechnology. 50(October), 148-159. DOI: 10.1016/ j.precisioneng.2017.05.002.

[7] Oryński, F. \& Synajewski, R. (2010). Surface roughness testing of conventionally treated surfaces and vibration on a surface grinder. Mechanik. 3, 190-192. (in Polish).

[8] Filipowski, R., Marcinak, M. (2000). Machining and erosion techniques. Warszawa: Oficyna Wydawnicza Politechniki Warszawskiej. 304-308. (in Polish).

[9] Starosta, R. (2008). Surface treatment. Gdynia: Wydawnictwo Akademii Morskiej w Gdyni. (in Polish).

[10] Bańkowski, D., Spadło, S. (2006). Influence of the smoothing conditions in vibro-abrasive for technically dry friction the parts made of steel X160CRMOV121. Metal 2016: 25th Anniversary International Conference on
Metallurgy And Materials (pp. 1019-1024). WOS:000391251200165

[11] Woźniak, K. (2017). Surface treatment in container smoothers. Warszawa: WNT. (in Polish).

[12] Brinksmeier, E. \& Giwerzew, A. (2005). Hard gear finishing viewed as a process of abrasive wear. Wear. 258, 62-69.

[13] Bańkowski, D. \& Spadło, S. (2017). The aplication of vibro abrasive machining for smoothing of castings. Archives of Foundry Engineering. 17(1), 169-173. WOS: 000398158200031.

[14] Rao, Suren B. (2009). Repair of aircraft transmission gears via isotropic superfinishing. Gear Technology. May.

[15] Eric, C., Ames. (2012). Repair of high-value high-demand spiral bevel gears by superfinishing. Gear Technology. October, 50-59.

[16] Davidson, D.A. (2002). Mass Finishing Processes. Metal Finishing Guidebook and Directory. New York. TAM surfaces are Elsevier Science; Published 2002.

[17] Massarsky, M.L., Davidson, D.A. (2002). Turbo-abrasive machining - a new technology for metal and non-metal part finishing. The Finishing Line. Vol. 18 No.4. Dearborn MI: Association of Finishing Processes. Society of Manufacturing Engineers. Oct. 30.

[18] Bankowski, D., Spadlo, S. (2017). Investigations of influence of vibration smoothing conditions of geometrical structure on machined surfaces. 4th International Conference Recent Trends in Structural Materials. Comat 2016; Volume: 179 Article Number: UNSP 012002. DOI.org/10.1088/1757899X/179/1/012002

[19] Kacalak, W. \& Tandecka, K., (2012). Effect of superfinishing methods kinematic features on the machined surface. J. Machine Engineering. 4, 35-48.

[20] Gillespie, LK. (1999). Deburring and Edge Finishing Handbook. Society of Manufacturing Engineers.

[21] Hashimura, M., Hassamontr, J. \& Dornfeld, D.A. (1999). Effect of in-plane exit angle and rake angles on burr height and thickness in face milling operation transactions of the ASME. Journal of Manufacturing Science and Engineering 121(1), 13-19.

[22] http://riad.usk.pk.edu.pl/ mnykiel/iim/23/dydaktyka/SkrSkry /C 2.html (14.06.2017)

[23] http://www.dostal.com.pl/metale-kolorowe-aluminium.html (14.06.2017)

[24] http://www.rollwasch.it/en. Vibro Dry Experience PL. Rollwasch Italiana S.p.a (14.06.2017)

[25] technical materials from MARDAB, www.mardab.pl (14.06.2017).

[26] Janecki, D., Stępień, K. \& Adamczak, S. (2010). Problems of measurement of barrel- and saddle-shaped elements using the radial method. Measurement. 43(5), 659-663. 